\title{
Research on the Impact of transportation Infrastructure on Industrial Structure
}

\author{
Sun Jingxiao ${ }^{1}$ \\ ${ }^{1}$ School of Economics and Management Beijing Jiaotong University Beijing, China
}

\begin{abstract}
This paper selects panel data from 31 provinces and cities in China from 2005 to 2018, establishes a benchmark panel regression model and introduces a dynamic panel model with hysteresis effects, which is aimed to study the impact of transportation infrastructure on the industrial structure. On a national scale, railways have a stronger driving effect than roads, and roads have an obvious driving effect on the secondary industry. From the perspective of different regions, highway plays an obvious role in promoting the tertiary industry in western China, while railway plays a positive role in promoting the industrial development in eastern and western China. From the perspective of control variables, the level of economic development, human capital and urbanization rate have a significant promotion effect on the tertiary industry, while a significant negative effect on the primary industry.
\end{abstract}

\section{Introduction}

As a key link between products and factors, transportation infrastructure is a basic industry for the development of national economy and plays an important role in accelerating the flow of production factors and promoting the optimization and upgrading of industrial structure. The report of the 19th National Congress of the Communist Party of China (CPC) pointed out that the open economy of a higher level should be developed and infrastructure construction should be promoted. In addition, the Outline for Building a Transport Power issued by the CPC Central Committee and the State Council in September 2019 further proposed to comprehensively improve urban transport infrastructure and build a modern transport power. With the rapid development of transportation infrastructure, the continuous promotion of industrial structure optimization and upgrading has attracted more and more attention. The contribution of the three industries in the national economy has been changing and the industrial structure has been gradually transformed. From a nationwide perspective, China's industrial structure is gradually changing from a structure supported by the secondary industry to a structure supported by the tertiary industry, which indicates that China's industrial structure is transforming to a more advanced direction. Therefore, this paper mainly studies the impact of transportation infrastructure construction on industrial structure, and further puts forward Suggestions for promoting industrial optimization and upgrading in China.

\section{Literature Review}

In recent years, China's transportation infrastructure construction has been greatly developed, playing an important role in the upgrading of industrial structure. As for the impact of transportation infrastructure construction on the change of industrial structure, different scholars have conducted researches with different methods. Song $\mathrm{M}$, Wang $\mathrm{S}$ and Fisher $\mathrm{R} \mathrm{J}^{[1]}$ used panel data to build a theoretical model of iceberg cost and industry transfer, and studied the impact of transportation development on different industries. The results show that the development of transportation industry has the most significant promoting effect on the primary industry. Wang Hui and Zhang Meiqing ${ }^{[2]}$ used spatial measurement method to study the spatial spillover effect of transportation infrastructure on service industry employment, and verified that China's transportation infrastructure has a positive role in promoting the development of service industry. Elnasri ${ }^{\left[{ }^{[3]}\right.}$ investigated the relationship between infrastructure construction and total factor productivity by establishing an error correction model. The results showed that infrastructure construction not only promoted the improvement of production factors, but also further promoted the upgrading of industrial structure. Luo Xubei $^{[4]}$ studied the role of transportation infrastructure investment in national and regional economic growth performance and simulated the impact of hypothetical infrastructure investment allocation on economic growth performance. By revising the market potential model, Jiang Huaxiong, Cai Hongyu and Meng Xiaochen ${ }^{[5]}$ studied the impact of high-speed rail on the industrial structure of Chinese cities. The results showed that highspeed rail increased the proportion of service industry and reduced the proportion of manufacturing industry. By selecting panel data, Li Huiling and Xu Yan ${ }^{[6]}$ studied the relationship between the construction of transportation locomotive facilities, the adjustment of industrial structure 
and the effect of poverty reduction, and concluded that there is a long-term two-way relationship between transportation investment and the adjustment of industrial structure.

Summarizing the research results of scholars, it can be found that most of the literature focuses on the relationship between transportation infrastructure and economic growth, and there are not enough literatures on the impact of transportation infrastructure from the industrial level. Based on previous studies, this paper constructed a dynamic panel model to explore the impact of transportation infrastructure on the change of industrial structure and put forward Suggestions for the optimization and upgrading of industrial structure and the realization of high-quality economic development.

\section{Models and Data}

\subsection{Model}

This paper selected the panel data of 31 provinces and cities in China from 2005 to 2018, and used the research model of Peng Dingyun ${ }^{[7]}$ and Zhang Wei ${ }^{[8]}$ to construct the reference panel regression model and the dynamic panel regression model with lag effect respectively.

$$
y_{i t}=\beta_{0}+\beta_{1} \text { trans }_{i t}+\beta_{2} Z_{i t}+u_{i t}+\varepsilon_{i t} \quad \text { (1) }
$$

Where, $i$ and $t$ respectively represent different provinces and years; $y_{i t}$ is the variable representing the industrial structure, expressed by the contribution rate of different industries to GDP, specifically expressed as the proportion of the added value of the primary, secondary and tertiary industries in the increase of GDP, i.e. first $t_{i t}$, second $_{i t}$, third $_{i t} ; \beta_{0}$ is a constant term; trans ${ }_{i t}$ represents the transport infrastructure level, including road $_{i t}$ and rail $_{i t} ;$ road $_{i t}$ represents the highway density of the $i$ province in the $t$ year, rail $_{i t}$ represents the railway density of the $i$ province in the $t$ year; $\beta_{1}$ is the coefficient reflecting the degree of influence of transportation infrastructure on industrial structure. $\beta_{1}>0$ indicates that transportation infrastructure will drive the upgrading of industrial structure. $Z_{i t}$ is on behalf of all kinds of control variables. $\beta_{2}$ reflect the degree of influence of these control variables on industrial structure; $u_{i t}$ reflect individual fixed effect; $\varepsilon_{i t}$ is the random error term.

Considering that the impact of transportation infrastructure on industrial structure is not a short-term effect but a long-term process, in order to make the model more accurate, hysteresis variables are added to build a panel regression model with hysteresis effect on the basis of the benchmark panel regression model, as shown in Equation (2).

$$
y_{i t}=\beta_{0}+\beta_{1} y_{i(t-1)}+\beta_{2} \text { trans }_{i t}+\beta_{3} Z_{i t}+u_{i t}+\varepsilon_{i t}
$$

On the basis of (1), the lag term of dependent variable is introduced. The lagged term of the dependent variable refers to the comprehensive influence of the past factor input on the current year's industrial structure change.

\subsection{Variables}

- Explained variable. This paper selects the proportion of the added value of the three industries in GDP, that is, the contribution rate of each industry to GDP, as the explained variable.

- explanatory variable. This paper studies the impact of traffic infrastructure on industrial structure. The level of traffic infrastructure is expressed by the density of traffic lines and divided into highway density and railway density. This index is commonly used by scholars to measure the level of traffic infrastructure. Highway density refers to the ratio of highway mileage to the area of each province, while railway density refers to the ratio of railway operating mileage to the area of each province.

- Control variables. The control variables are economic growth level, human capital, investment level, government financial expenditure, opening-up level and urbanization rate. Among them, the level of economic growth will have a certain impact on the industrial structure. In this paper, the GDP deflator in the base period of 2008 was used to calculate the real per capita GDP, and its logarithm was used to represent the level of economic growth.

The selection of variables in this paper is shown in Table1.

\begin{tabular}{|c|c|c|}
\hline Variables & $\begin{array}{c}\text { Symb } \\
o l\end{array}$ & explanation \\
\hline \multicolumn{3}{|c|}{ Explained variables } \\
\hline $\begin{array}{l}\text { The } \\
\text { contribution of } \\
\text { primary } \\
\text { industry to } \\
\text { GDP }\end{array}$ & first $_{i t}$ & $\begin{array}{l}\text { The proportion of the added value of the } \\
\text { primary industry in GDP }\end{array}$ \\
\hline $\begin{array}{l}\text { The } \\
\text { contribution of } \\
\text { secondary } \\
\text { industry to } \\
\text { GDP }\end{array}$ & second $_{i}$ & $\begin{array}{l}\text { The proportion of the added value of the } \\
\text { secondary industry in GDP }\end{array}$ \\
\hline $\begin{array}{l}\text { The } \\
\text { contribution of } \\
\text { tertiary } \\
\text { industry to } \\
\text { GDP }\end{array}$ & third $_{i t}$ & $\begin{array}{l}\text { The proportion of the added value of the } \\
\text { tertiary industry in GDP }\end{array}$ \\
\hline \multicolumn{3}{|c|}{ Explanatory variables } \\
\hline Road density & $\operatorname{road}_{i t}$ & $\begin{array}{l}\text { The ratio of highway length to the area } \\
\text { of the province }\end{array}$ \\
\hline $\begin{array}{l}\text { Railway } \\
\text { density }\end{array}$ & rail $_{i t}$ & $\begin{array}{l}\text { The ratio of railway mileage to the area } \\
\text { of the province }\end{array}$ \\
\hline \multicolumn{3}{|l|}{ Control variables } \\
\hline $\begin{array}{ll}\begin{array}{l}\text { Level } \\
\text { economic } \\
\text { growth }\end{array} & \\
\end{array}$ & $e c o_{i t}$ & The log of real GDP per capita \\
\hline Human capital & $h r_{i t}$ & $\begin{array}{l}\text { Ratio of tertiary education and above to } \\
\text { those aged } 6 \text { and above }\end{array}$ \\
\hline $\begin{array}{l}\text { Investment } \\
\text { level }\end{array}$ & invest $_{i t}$ & Log value of fixed asset investment \\
\hline $\begin{array}{l}\text { Fiscal } \\
\text { expenditure }\end{array}$ & $g o v_{i t}$ & $\begin{array}{l}\text { The logarithm of government } \\
\text { expenditure }\end{array}$ \\
\hline $\begin{array}{l}\text { Level of } \\
\text { Opening up }\end{array}$ & trade $_{i t}$ & $\begin{array}{l}\text { Log value of total import and export } \\
\text { trade }\end{array}$ \\
\hline $\begin{array}{l}\text { Urbanization } \\
\text { rate }\end{array}$ & urban $_{i t}$ & $\begin{array}{l}\text { The ratio of urban population to total } \\
\text { population }\end{array}$ \\
\hline
\end{tabular}

Table1. Summary of Variables 


\subsection{Data}

The data selected in this paper are panel data of 31 provinces and cities from 2005 to 2018. The data are mainly from China Statistical Yearbook and China Macroeconomic Database over the years, among which some missing data are supplemented by interpolation method. In addition, in order to improve the fitting degree of the model, logarithmic processing is carried out on the data.

\section{Analysis of Empirical Results}

\subsection{Stationarity Test}

In order to avoid the phenomenon of "false regression" and ensure the accuracy of the model, unit root test was carried out for each variable to ensure the stability of the data. In this paper, LLC test and PP-Fisher test are used to conduct unit root test on panel data, and the results are shown in Table 2. If the data passes the test, it means that the result is stable, there is no unit root in the model, and otherwise it is unstable. The unstable variable can pass the stationarity test to show that the variable is stable after the first-order difference.

Table2. Unit Root Test for Variables

\begin{tabular}{|c|c|c|c|}
\hline \multirow{2}{*}{ Variables } & \multicolumn{3}{|c|}{ Inspection methods } \\
\hline & $L L C$ & IPS & PP-Fisher \\
\hline first $_{i t}$ & $0.000 * * *$ & $0.094 *$ & $0.000 * * *$ \\
\hline second $_{i t}$ & $0.000 * * *$ & 0.220 & $0.000 * * *$ \\
\hline third $_{i t}$ & $0.007 * * *$ & 0.105 & $0.033^{* *}$ \\
\hline $\operatorname{road}_{i t}$ & 0.572 & 0.218 & $0.000 * * *$ \\
\hline rail $_{i t}$ & $0.000 * * *$ & 0.297 & $0.000 * * *$ \\
\hline$e c o_{i t}$ & $0.000 * * *$ & $0.005 * * *$ & 0.106 \\
\hline$h r_{i t}$ & $0.000 * * *$ & $0.047^{* *}$ & $0.000 * * *$ \\
\hline invest $_{i t}$ & $0.000 * * *$ & $0.001 * * *$ & $0.000 * * *$ \\
\hline$g o v_{i t}$ & $0.000 * * *$ & $0.000 * * *$ & $0.000 * * *$ \\
\hline trade $_{i t}$ & $0.000 * * *$ & $0.006 * * *$ & $0.000 * * *$ \\
\hline$u_{r b a n}$ & $0.008 * * *$ & 0.553 & $0.000 * * *$ \\
\hline
\end{tabular}

Note: $* * * * * *$ show that they respectively pass the inspection in $1 \%, 5 \%$ and $10 \%$ signifi cance levels.

\subsection{Regression Analysis}

In this paper, panel data of 31 provinces, autonomous regions and municipalities in China from 2005 to 2018 are selected. According to formula (2) of the panel data regression model, the results are shown in Table 3. Considering that lag term of dependent variable is introduced into the model, the estimator obtained by static panel data model is inconsistent. Therefore, this paper refers to Zhang Jingbo's ${ }^{[9]}$ research method and USES GMM method for regression.

Regression (1) (3) indicate that the same explanatory variable is used to conduct regression for different explained variables respectively. Meanwhile, AR (1), AR (2) and Sargan test are carried out for regression results in this paper. According to AR (1) and AR (2) test results in the table, there is no sequential autocorrelation in the residual terms of regression (1) (3). Sargan test results are all over 0.05 , so the null hypothesis that all instrumental variables are valid can be accepted. Based on the above test results, we can conclude that the GMM estimation method used in this paper is feasible and the regression results are robust.

Looking from the explanatory variables, railway density on the influence of the first industry is negative, and a significant at $1 \%$ level, the influence of the density of the second industry and railway is positive, and significant under 5\% level, railway density of the second industry and the tertiary industry has obvious role in promoting, at the same time road density on the second industry also has a role in promoting. This may be because the secondary industry is mainly industry, and transportation infrastructure will affect the transportation of raw materials, accelerate the flow of resources, and promote industrial development.

From the perspective of control variables, the level of economic development, human capital and urbanization rate have a significant promotion effect on the tertiary industry, while a significant negative effect on the primary industry. Compared with the primary industry and the secondary industry, the development of the tertiary industry requires more effective allocation of capital and talents, and the improvement of economic development plays an important role in promoting the upgrading and transformation of industrial structure.

Table3. Regression Results for Different Explained Variables

\begin{tabular}{|c|c|c|c|}
\hline $\begin{array}{c}\text { regressio } \\
\text { n model }\end{array}$ & (1) & (2) & (3) \\
\hline Variables & first $_{i t}$ & second $_{i t}$ & third $_{i t}$ \\
\hline $\operatorname{road}_{i t}$ & $\begin{array}{c}0.015 \\
(0.561)\end{array}$ & $\begin{array}{l}0.100 * * \\
(0.043)\end{array}$ & $\begin{array}{c}-0.046 \\
(0.493)\end{array}$ \\
\hline rail $_{i t}$ & $\begin{array}{c}-0.653^{* * *} \\
(0.001)\end{array}$ & $\begin{array}{l}0.225 * * \\
(0.023)\end{array}$ & $\begin{array}{l}0.570 * * \\
(0.015)\end{array}$ \\
\hline$e c O_{i t}$ & $\begin{array}{c}-0.025 * * * \\
(0.000)\end{array}$ & $\begin{array}{c}0.254 * * * \\
(0.000)\end{array}$ & $\begin{array}{c}0.280 * * * \\
(0.000)\end{array}$ \\
\hline$h r_{i t}$ & $\begin{array}{c}-0.040 * * \\
(0.025)\end{array}$ & $\begin{array}{c}-0.198 * * * \\
(0.008)\end{array}$ & $\begin{array}{c}0.288 * * * \\
(0.009)\end{array}$ \\
\hline invest $_{i t}$ & $\begin{array}{c}0.007 \\
(0.182)\end{array}$ & $\begin{array}{c}-0.044 * * * \\
(0.000)\end{array}$ & $\begin{array}{c}0.001 \\
(0.976)\end{array}$ \\
\hline$g_{o v} v_{i t}$ & $\begin{array}{c}0.003 \\
(0.140)\end{array}$ & $\begin{array}{l}-0.012 * \\
(0.072)\end{array}$ & $\begin{array}{c}0.057 * * * \\
(0.000)\end{array}$ \\
\hline trade $_{i t}$ & $\begin{array}{l}0.004 * * \\
(0.017)\end{array}$ & $\begin{array}{c}0.003 \\
(0.450)\end{array}$ & $\begin{array}{c}-0.032 * * * \\
(0.000)\end{array}$ \\
\hline$u_{\text {rban }}$ & $\begin{array}{c}-0.147 * * * \\
(0.001)\end{array}$ & $\begin{array}{l}-0.28 * * \\
(0.013)\end{array}$ & $\begin{array}{c}0.746^{* * * *} \\
(0.000)\end{array}$ \\
\hline$y_{i(t-1)}$ & $\begin{array}{c}0.524 * * * \\
(0.000)\end{array}$ & $\begin{array}{c}0.391 * * * \\
(0.000)\end{array}$ & $\begin{array}{c}0.1721 * * * \\
(0.001)\end{array}$ \\
\hline AR (1) & 0.296 & 0.005 & 0.002 \\
\hline $\mathrm{AR}(2)$ & 0.446 & 0.167 & 0.668 \\
\hline $\begin{array}{c}\text { Sargan } \\
\text { test }\end{array}$ & 0.328 & 0.247 & 0.167 \\
\hline
\end{tabular}

Note: $* * * * *, *$ show that they respectively pass the inspection in $1 \%, 5 \%$ and $10 \%$ significance 


\subsection{Spatial Sample Regression}

China has a vast land area, and the development of different regions is quite different. 31 provinces can be geographically divided into four regions: the east, the middle, the west and the northeast. Therefore, this paper further studies these four regions and uses the benchmark model to regression the relationship between transportation infrastructure and industrial structure in different regions.

Table4. Spatial Sample Regression Results

\begin{tabular}{|c|c|c|c|}
\hline \multirow{2}{*}{ Area } & \multicolumn{3}{|c|}{ Explanatory variables } \\
\hline & first $_{i t}$ & second $_{i t}$ & third $_{i t}$ \\
\hline \multicolumn{4}{|l|}{ East } \\
\hline road $_{i t}$ & -0.876 & 0.345 & 0.589 \\
\hline rail $_{i t}$ & $-0.692 *$ & $0.246 * * *$ & 0.854 \\
\hline \multicolumn{4}{|l|}{ Middle } \\
\hline $\operatorname{road}_{i t}$ & $0.245^{* *}$ & -0.428 & * $\quad 0.256^{* *}$ \\
\hline rail $_{i t}$ & 0.644 & $0.212 * * *$ & $-0.069 *$ \\
\hline \multicolumn{4}{|l|}{ West } \\
\hline $\operatorname{road}_{i t}$ & -0.659 & 0.855 & * $\quad 0.832 * *$ \\
\hline rail $_{i t}$ & $-0.098 * * *$ & 0.241 & $\frac{-}{1.051^{* *}}$ \\
\hline \multicolumn{4}{|c|}{ northeast } \\
\hline $\operatorname{road}_{i t}$ & -1.264 & $-0.872 * *$ & 0.698 \\
\hline rail $_{i t}$ & 0.216 & 0.534 & 0.263 \\
\hline
\end{tabular}

Note: *****,*show that they respectively pass the inspection in $1 \%, 5 \%$ and $10 \%$ significance

As can be seen from Table 4, there are obvious differences in the impact of transportation infrastructure development on regional industrial structure. Railway has a more significant impact on the development of the secondary industry in the eastern and central regions, but a negative impact on the development of the tertiary industry in the western region. The impact of highways on the eastern region is not significant, while the impact on the tertiary industry in the western region is significantly positive. The reason may be that the tertiary industry in the western region is relatively backward compared with other regions, so the convenience of highways has an obvious effect on the development of its industry.

\section{Conclusions}

In this paper, panel data of 31 provinces and autonomous regions in China from 2005 to 2018 are selected and studied by using the benchmark panel regression model and the dynamic panel regression model with hysteresis effect added. The following conclusions are :

On the whole, different transportation infrastructures have different influences on the industrial structure. Railways have a stronger driving effect than highways, and highways have an obvious driving effect on the secondary industry, while railways have a negative influence on the primary industry.

From the perspective of different regions, the impact of transportation infrastructure development on regional industrial structure is obviously different. Highway plays an obvious role in promoting the tertiary industry in western China, while railway plays a positive role in promoting the industrial development in eastern and western China.

From the perspective of control variables, the level of economic dev elopment, human capital and urbanization rate have a significant promotion effect on the tertiary industry, while a significant negative effect on the primary industry.

\section{Acknowledgment}

I would like to express my heartfelt thanks to everyone who helped me. First of all, I would like to thank the experts and judges who reviewed my article. Their Suggestions have made me constantly improve and improve myself. Secondly, I would like to thank my postgraduate tutor for his guidance and help. I am more professional and rigorous in academic study. In addition, I would like to thank my classmates. It is their encouragement that gives me the courage and strength to persevere.

\section{References}

1. Song M, Wang S, Fisher R J, et al. Transportation, iceberg costs and the adjustment of industrial structure in China[J]. Transportation Research Part Dtransport and Environment, 2014: 278-286.

2. Wang $H$, Zhang M. Does China's transportation infrastructure have an impact on employment in the service sector?[J]. Kybernetes, 2020.

3. Elnasri A . The Impact of Public Infrastructure on Productivity: New Evidence for Australia[R] . Sydney: Australian School of Business Working Paper, 2014.

4. Luo, Xubei. China's Lagging Region Development and Targeted Transportation Infrastructure Investments [J].Annals of Economics and Finance, 2014(15): 365-409.

5. Jiang H, Cai H, Meng X. Research on the influence of high-speed railway on the industrial structure of Chinese cities [J]. Human geography,2017,32(05):132-138.

6. Li Huiling, Xu Yan. Research on Transportation Infrastructure, Industrial Structure and Poverty Reduction Effect -- Based on panel VAR Model [J]. Technology Economics and Management Research,2016(08):25-30.

7. Peng D, Wang Y. Study on the influence of transport infrastructure on industrial structure change $[\mathrm{J}]$. Journal of Beijing university of posts and telecommunications (social science edition),2019,21(04):30-41.

8. Zhang W, Liang Y. Research on the relationship between transportation infrastructure, population 
agglomeration and industrial structure upgrading in chengdu-chongqing urban agglomeration $[\mathrm{J}]$. Project management technology,2020,18(04):49-54.

9. Zhang Jingbo. Research on the Impact of Transportation Infrastructure Construction on industrial Structure Transformation $[\mathrm{J}]$. Journal of Yunnan University of Finance and Economics, 2015,34(11):35-46. 